\title{
A comparative study of single and double dose of intracervical Prostaglandin E2 gel for cervical ripening
}

\author{
Parate $\mathbf{S}^{1}$, Fidvi $\mathbf{J}^{2}$
}

Dr Smita Parate, Associate professor, Department of Obstetric and Gyenecology, K D Medical college \& research centre, Mathura, UP, Dr Juzar Fidvi, Associate professor, Indira Gandhi Medical college, Nagpur, India.

Address for correspondence: Dr Smita Parate, Email: advisorshukla@ gmail.com

\begin{abstract}
Introduction: Induction of labour should be safe for both the mother and baby that is a method with short induction delivery interval, absence of side effects and conveniences for both the patients and medical staffs. A lamp of success was lit with the introduction of prostaglandins, one of the factor that influences successful induction of labor. Material $\&$ methods: A case control study was carried out in department of obstetrics and gynecology in tertiary care teaching hospital of North India. A total 100 patients were taken in two groups, 50 patients of study group were induced with two doses of PGE2 gel, 6 hours apart and 50 patients of control group were induced with single dose of PGE2 gel given intracervically. Results: In this study age group of the patients ranges from 18-35 years and the parity was up to para 4 . It was evident that major indication of induction of labor was PIH and post dated pregnancies. All the patients had Bishop score 4 or less indicating an unripe cervix. There was significant increase in mean Bishop score after second dose instillation in study.ie 6.84 as compared to control group where second dose were not instilled. Mean induction delivery interval in study group is $13.14 \mathrm{hrs}$ as compared to controls $16.37 \mathrm{hrs}$. 25 out of 50 patients in study group delivered within $12 \mathrm{hrs}$ as compared to 6 out of 50 patients in control groups. Conclusion: The above study concluded that intracervical double dose of PGE2 gel is significantly effective for pre induction cervical ripening and $94 \%$ of patients went into labor spontaneously without requiring stimulation by other oxytosis.
\end{abstract}

Key words: cervical ripening, prostaglandin, oxytocin, labour induction.

\section{Introduction}

Induction of labor is resorted in the conditions where continuation of pregnancy may be hazardous to mother or fetus. Also planned induction of labour has become an accepted procedure in modern obstetrics practice. It is indicated when the benefits to either the mother or fetus outweigh those of continuing the pregnancy [1]. Induction of labor should be simple, safe, effective and preferably non-invasive. The success of induction depends to a large extent on the consistency, compliance and configuration of the cervix [2]. The unripe cervix thus remains a well recognized impendent to the successful induction of labour [3].

Local application of Prostaglandin E2 (PGE2 or Dino-

Manuscript received: $2^{\text {nd }}$ Jan 2015

Reviewed: $14^{\text {th }}$ Jan 2015

Author Corrected: $14^{\text {th }} \mathrm{Feb} 2015$

Accepted for Publication: $24^{\text {th }}$ Feb 2015 prostone) has been in use for cervical ripening since late 1960s. PGE2 administered intravaginally or intracervically, improves Bishop Score and induction to delivery time when compared to those of untreated controls. The local application of PGE2 results in direct softening of the cervix by a number of different mechanisms [4,5]. Uterine tachysystole and accompanying fetal distress is reported following administration of PGE2 in 1 to 5 per-cent of women [6]. State of the cervix is one of the important predictors of successful labour induction. In 1964, Bishop described a scoringsystem based on cervical examination that predicted vaginal delivery in multiparous women. If the cervix is unfavorable (Bishop score $\leq 6$ ), cervical ripening is warranted prior to labor induction [7].

The present study was designed to evaluate the efficacy and safety of intracervical prostaglandin, given to 
patients with unfavorable bishop score with two doses of PGE2 gel preparation, 6 hours apart and comparison was done with single dose.

\section{Material \& methods}

Study area: The present case-control study was carried out in the department of obstetrics and gynecology in tertiary care teaching hospital of North India.

Inclusion criteria: singleton pregnancy with cephalic presentation with intact membranes having gestational age of 28 weeks and above, and Bishop score of less than 5 .

Exclusion criteria: The patients were disqualified from study if they, had previous uterine surgery, vaginal bleeding or parity of $>5$ or other contraindication to PGs like Asthma, glaucoma, sickle cell disease etc.

A total 100 patients were taken in two groups, 50 patients of study group were induced with two doses of PGE2 gel, 6 hours apart and 50 patients of control group were induced with single dose of PGE2 gel given intracervically. Following hospitalization, the patients were assessed to determine the modified Bishop score. The patients having unfavourable cervix i.e. Bishop

\section{Results}

There were total 100 patients were studied, 50 in each group. In the control group single instillation of endocervical PGE2 gel was done whereas in study group a double dose of PGE2 gel instillation was done 6 hours apart.

Table No 1: Distribution of patients according to bishop score

\begin{tabular}{|l|l|l|}
\hline Bishop Score & Study Group & Control Group \\
\hline 0 & 7 & 2 \\
\hline 1 & 21 & 9 \\
\hline 2 & 12 & 6 \\
\hline 3 & 10 & 18 \\
\hline 4 & 0 & 15 \\
\hline TOTAL & 50 & 50 \\
\hline
\end{tabular}

It shows all patients in study and control groups who had Bishop Score 4 or less, indicating an unripe cervix.

Table No 2: Mean bishop score at 0 hour, 6 hours, and 12 hours

\begin{tabular}{|l|l|l|}
\hline Mean Bishop Score & \multicolumn{1}{|c|}{ Study Group } & \multicolumn{1}{c|}{ Control Group } \\
\hline At 0 hour & $1.50+0.97$ & $2.7+1.20$ \\
& $(\mathrm{P}<0.001)$ & \\
\hline At 6 hour & $4.56+0.93$ & $5.80+1.87$ \\
& $(\mathrm{P}<0.001)$ & \\
\hline At 12 hour & $11.40+2.16$ & $8.79+2.04$ \\
& $(\mathrm{P}<0.001)$ & \\
\hline
\end{tabular}

There was increase in mean Bishop score by 3.06 in study group within 6 hrs after single dose instillation and also in control group, mean bishop score increased by 3.10 with in $6 \mathrm{hrs}$, the difference was not significant ,but there was significant increase in mean bishop score after second dose instillation in study group i.e 6.84 as compared to control 
group where second dose was not instilled, i.e 2.99.so it is concluded that bishop score increased was highly significant after second dose.

Table No 3: Mean induction delivery interval and contraction delivery interval in both groups.

\begin{tabular}{|l|l|l|}
\hline Group & $\begin{array}{l}\text { Mean Induction Delivery Interval } \\
(\mathrm{Hrs})\end{array}$ & $\begin{array}{l}\text { Mean Contraction Delivery Interval } \\
\text { (Hrs) }\end{array}$ \\
\hline Study Group & $13.14+6.24$ & $10.76+5.00$ \\
\hline Control Group & $16.37+5.34$ & $14.54+4.96$ \\
\hline
\end{tabular}

The mean induction delivery interval in study group is $13.14 \mathrm{hrs}$ as compared to $16.37 \mathrm{hrs}$ in control group. $\mathrm{P}<0.01$ which is highly significant). As well as mean contraction delivery interval in study group is $10.76 \mathrm{hrs}$ as compared to $14.54 \mathrm{hrs}$ in control group. $(\mathrm{P}<0.01)$.

From the above comparison it can be stated that there is significant reduction in induction delivery interval after second dose instillation.

Table No 4: Number of spontaneous delivery in 12 hours in both groups

\begin{tabular}{|l|l|l|}
\hline Group & No. Of Patients Delivered In It Hour & Percentage \\
\hline Study Group & 25 & $50 \%$ \\
\hline Control Group & 06 & $12 \%$ \\
\hline
\end{tabular}

In the study group $25 / 50$ patients delivered within $12 \mathrm{hrs}$ as compared to $6 / 50$ patients in control group. $\mathrm{P}<0.01$ (highly significant)

Table No 5: Mode of delivery in each group

\begin{tabular}{|l|l|l|}
\hline Group & Normal Delivery & Caesarean Section \\
\hline Study Group & $46(92 \%)$ & $4(8 \%)$ \\
\hline Control Group & $42(84 \%)$ & $8(16 \%)$ \\
\hline
\end{tabular}

It is concluded that percentage of caesarean section is twice in control group as compared to study group.

Table no 6: Indication of LSCS in both groups

\begin{tabular}{|l|l|l|}
\hline Indication & Study Group & Control Group \\
\hline Failed Induction & 0 & 2 \\
\hline Fetal Distress & 3 & 5 \\
\hline $\begin{array}{l}\text { Prolonged First } \\
\text { Stage }\end{array}$ & 1 & 1 \\
\hline Total & 4 & 8 \\
\hline
\end{tabular}

In study group only $3 / 50$ patients required induction with Pitocin as compared to $18 / 50$ in control groups, result is highly significant $\mathrm{P}<0.01$. 


\section{Discussion}

In this study we found that the intracervical double dose of PGE2 gel is significantly effective for preinduction of cervical ripening and $94 \%$ of patients went into labour spontaneously without requiring stimulation by other oxytocis. The mean induction delivery interval in the study group was at $13.14 \mathrm{hrs}$ as compared to $16.37 \mathrm{hrs}$ in control group and this difference was statistically highly significant $(\mathrm{P}<0.01)$. The findings of our study were consistent with the findings reported by Mundle and Young [8] and Bartha et al [9]. The proportion of women who underwent cesarean section was twice as higher in the control group. Our findings were consistent with those reported by Mundle and Young [8] and Wing et al [10 However Krishnamurthy [11] found that Misoprostol alone was more effective and highly inexpensive alternative to the combination of dinoprostone and oxytocin for labor induction. They also compared the safety, efficacy, cost and fetal outcome of misoprostol with that of combination of dinoprostone and oxytocin for induction of labor. Patients were randomized to receive either misoprostol $25 \mu \mathrm{g}$ intravaginally every 4 hours for a maximum of 8 doses (study group $\mathrm{n}=37$ ) or dinoprostone $0.5 \mathrm{mg}$ intracervically 6 hourly for a maximum of 3 doses followed by oxytocin if necessary (control group $n=35$ ).

A 2006 Cochrane review included 9 trials (2627 women) that compared oral misoprostol to vaginal dinoprostone and found that women who received oral misoprostol were less likely to have a CS [12].

A Cochrane review [13] compared the effects of different doses of vaginal misoprostol an found that Lower doses i.e $25 \mathrm{mcg}$ was better in form of less uterine hyperstimulation, with and without fetal heart rate changes, but required more oxytocin induction. A comparison [14] between $25 \mathrm{mcg}$ and $50 \mathrm{mcg}$ intravaginal misoprostol for cervical ripening and labour induction showed the higher dose was associated with as shorter interval to vaginal delivery, greater proportion of deliveries within 24 hours, and less frequent need for oxytocin augmentation, but it is unclear whether it is as safe as the $25 \mathrm{mcg}$ doses. Another similar study [15] showed the same results in relation to time to delivery and need for oxytocin augmentation. In contrast, more women achieved vaginal delivery with 25 microg misoprostol(79.3 vs. $60.7 \%$; $<<0.05$ ).
A more recent RCT [16] compared two schedules of intravaginal misoprostol: 100 microg, every 6 hours or 50 microg every 4 hours. In the two groups the number of doses of misoprostol used were similar. There was no difference between the two groups in the time to delivery and cesarean rate. Likewise, there was no significant difference in the rates of $5 \mathrm{~min}$ Apgar score and meconium passage.

Another RCT [17] compared the effectiveness of 25 microg vs. 50 microg of intravaginal misoprostol for cervical ripening and labor induction beyond 41 weeks' gestation. The dose was repeated every 4 hours (maximum number of doses limited to six) until the patient exhibited three contractions in $10 \mathrm{~min}$. There was no significant difference between the two groups with regard to the induction-vaginal delivery interval $(685 \pm 201 \mathrm{~min}$ in the 25 microg group vs. $627 \pm 177 \mathrm{~min}$ in the 50 microg group, $\mathrm{P}=0.09$ ). The proportion of women delivering vaginally with one dose of vaginal misoprostol was significantly greater in the 50 microg group (0/49 vs.41/47, $\mathrm{P}<0.001)$. There were no differences in the rates of cesarean and operative vaginal delivery rates, or in the incidences of tachysystole and hyperstimulation syndrome in the two treatment groups. Neonatal outcomes were also similar.

A study [18] performed in multiparous patients randomised 104 women to either a single dose of 50 microg of intravaginal misoprostol in 24 hours, or two consecutive doses of intravaginal 50 microg misoprostol 6 hours apart. The mean induction-todelivery interval and delivery rate within 12 hours were higher in the two-dose group. The oxytocin augmentation rate was higher in the single dose group. There was no statistical difference between both regimens with respect to the rates of tachysystole, hyperstimulation, and meconium staining at delivery.

Diro M, Adra Aet al[19] conducted study to compare the efficacy and safety of two dosing regimens of misoprostol for cervical ripening and labor induction , they found Patients in the 50 microg group had a shorter first stage (848 min vs. $1,122 \mathrm{~min}, \mathrm{P}<0.007$ ), shorter induction-to-vaginal delivery interval (933 $\mathrm{min}$ vs. $1,194 \mathrm{~min}, \mathrm{P}<0.013)$, decreased incidence of oxytocin augmentation $(53.9 \%$ vs. $68 \%, \mathrm{P}<0.015)$, and decreased total units of oxytocin $(2,763 \mathrm{mU}$ vs. 5,236 $\mathrm{mU}, \mathrm{P}<0.023)$, but there was a higher hyperstimulation rate $(19 \%$ vs. $7.2 \%, \mathrm{P}<0.005)$.

There are further studies comparing two types of prostaglandin for labor induction. In the study kudagi et 
al of 40 women, the mean induction delivery was shorter and the average interval ranged from 3 - 10.7 and 4.9 - $16.4 \mathrm{hrs}$ in misoprostol and dinoprostone group respectively as compared to oxytocin.[20] and was in accordance with the study by Nanda et al[21] the no. of vaginal deliveries were $75 \%$ in misoprostol group compared to $60 \%$ in dinoprostone gel group . Gupta $\mathrm{N}$ et al [22], have also reported that spontaneous vaginal deliveries were $86 \%$ in misoprostol group compared to $68 \%$ in dinoprostone gel. The interval from the application of the initial dose to the beginning of active phase of the labour, induction - delivery intervals were shorter in misoprostol group with no change in Bishop's score (Table 2 and Table 3). These results were quiet consistent with the study conducted by Belfrage et al[23], Neiger et al[24], Buser et al[25]. Oxytocin requirement for augmentation was $10 \%$ in misoprostol group compared to $45 \%$. This was similar to the study by Danielian et al [26], which mentioned $21 \%$ in the misoprostol group and $47 \%$ in the dinoprostone gel group . Maternal and foetal complications were less in dinoprostone gel group but there was no significant statistical difference (30\% vs 5\%) for uterine hyper stimulation and (30\% vs 5\%) for meconium staining of liquour in misoprostol group and dinoprostone gel group respectively . Chuck et al [20], also reported that no significant differences were noted in maternal and foetal effects. Rates of caesarean sections were less in misoprostol group ( $25 \%$ vs $40 \%$ ) than dinoprostone gel group but statistically insignificant. Jouatte These results were quiet consistent with the study conducted by Belfrage et al[23], Neiger et al[24], and Buser et al[25].

\section{Conclusion}

From the above study it is concluded that, intracervical double dose of prostaglandin gel instillation decreases induction delivery interval significantly and patients progress into labour spontaneously without requiring stimulation with other oxytosis. PGE2 gel can be used safely and effectively in double dose for cervical ripening in patients needing induction of labour.

Funding: Nil, Conflict of interest: None

Permission of Ethical committee: Yes

\section{References}

1. Brindley BA, Sokol RJ. Induction and Augmentation of Labor. Basis and Methods for Current Practice. Obstet Gynecol Surv. 1988 Dec;43(12):730-43.
2. K. Dahiya, K. Malik, A. Dahiya and S. Nanda. Comparison of the Efficacy of Foley Catheter Balloon with Dinoprostone Gel for Cervical Ripening at Term. International Journal of Clinical Medicine, Vol. 3 No. 6, 2012, pp. 527-531. doi: 10.4236/ijcm.2012.36095.

3.Osaheni Lucky Lawani,1 Azubuike Kanario Onyebuchi,2 Chukwuemeka Anthony Iyoke Obstetric Outcome and Significance of Labour Induction in a Health Resource Poor Setting. Hindawi Publishing Corporation Obstetrics and Gynecology International Volume 2014, Article ID 419621, 5 pages http://dx.doi.org/10.1155/2014/419621

4. N. Uldbjerg, G. Ekman and A. Malmstrom. Ripening of the Human Uterine Cervix Related to Changes in Glyco-saminoglycans and Collagenolytic Activity. American Journal of Obstetrics \& Gynecology, Vol. 147, No. 6, 1983, pp. 662-666. Available on search.scirp.org

5. K. F. Trofatter, D. Bowers, R. N. Standby, A. Gall and A. P. Killam, "Preinduction Cervical Ripening with Pros-taglandin E2 Gel," American Journal of Obstetrics \& Gynecology, Vol. 153, No. 3, 1985, pp. 268-271. Available onsearch.scirp.org/references/7427369

6. R. P. Prins, R. N. Bolton and C. Mark, "Cervical Ripen-ing with Intravaginal Prostaglandin E2 Gel," Obstetrics \& Gynecology, Vol. 63, 1984, pp. 697-702 available on www.jourlib.org/references/7427370

7. Bishop EH. Pelvic scoring for elective induction. Obstet Gynecol. 1964 Aug;24:266-8.

8. Mundle WR, Young DC. Vaginal misoprostol for induction of labor: a randomized controlled trial. Obstet Gynecol. 1996 Oct;88(4 Pt 1):521-5..

9. Bartha TL, Comino-Delgado R, Garcia-Benasach F et al. Oral misoprostol and intracervical dinoprostone for cervical ripening and labor induction: a randomized comparison. Obstet Gynecol2000;96:465-9. avilable on medind.nic.in

10. Wing DA, Jones MM, Rahall A et al. A comparison of misoprostol and prostaglandin E2 gel for preinduction cervical ripening and labor induction. Am J Obstet Gynecol. 1995 Jun;172(6):1804-10.

11. Murthy Bhaskar Krishnamurthy, Arkalgud Mangala Srikantaiah. Misoprostol alone versus a combination of dinoprostone and oxytocin for induction of labor. J Obstet Gynecol India Vol. 56, No. 5 : 
September/October 2006 Pg 413-416. Available onhttp://medind.nic.in

12. Alfirevic Z, Weeks A. Oral misoprostol for induction of labour. Cochrane Database Syst Rev2006;( 2): CD001338. DOI: $\quad 10.1002 / 14651858$. CD001338.pub2.

13. Hofmeyr GJ, Gülmezoglu AM. Vaginal misoprostol for cervical ripening and induction of labour (Cochrane Review). In: The Cochrane Library, Issue 4, 2004. Oxford: Update Software.available onhttps://books.google.co.in

14 Sanchez-Ramos L, Kaunitz AM, Delke I. Labour induction with 25 microg versus 50 microg intravaginal misoprostol: a systematic review. Obstet Gynecol 2002; 99: 145-151.available on archives.who.int

15. Has R, Batukan C, Ermis H, Cevher E, Araman A, Kilic G, Ibrahimoglu L. Comparison of 25 and 50 microg vaginally administered misoprostol for preinduction of cervical ripening and labour induction. Gynecol Obstet Invest 2002; 53:16-21.available on pjmhsonline.com

16. Ozsoy M, Ozsoy D. Induction of labor with 50 and 100 microg of misoprostol: comparison of maternal and fetal outcomes. Eur J Obstet Gynecol Reprod Biol 2004; 113: 41-44.available on europepmc.org

17. Meydanli MM, Çalıkan E, Burak F, Narin MA, Atmaca R. Labor induction post-term with 25 micrograms vs. 50 micrograms of intravaginal misoprostol. Int J Gynaecol Obstet. 2003 Jun;81(3):249-55.

18. Lokugamage AU, Forsyth SF, Sullivan KR, El Refaey H, Rodeck CH. Randomized trial in multiparous patients: investigating a single vs. two-dose regimen of intravaginal misoprostol for induction of labor. Acta Obstet GynecolScand 2003; 82(2):138-142.

19.Diro $\mathrm{M}^{1}$, Adra A, Gilles JM, Nassar A, Rodriguez A, Salamat SM, Beydoun SN, O'Sullivan MJ, Yasin
SY, Burkett G. A double-blind randomized trial of two dose regimens of misoprostol for cervical ripening and labor induction. J Matern Fetal Med. 1999 MayJun;8(3):114-8.

20. B.L. KUDAGI, L. SAILAJA1, R. PRAVIN KUMAR1, C. SURESH BABU. a comparitive study of intravaginal misoprostol with intra cervical dinoprostone gel for induction of labour in pregnancy Asian J Pharm Clin Res, Vol 6, Issue 2, 2013, 174-178.

21.Smiti Nanda, Savita Rani, Singhal, Akta Papneja. Induction of labour with intravaginal Misoprostol and prostaglandin E2 gel: A comparative study. Trop Doct. 2007;37:21-4.

22. Gupta N, Mishra SL, Jain Shradha. A randomized clinical trial comparing misoprostol and dinoprostone for cervical ripening and labour induction. J Obstetrics and Gynaecology 2006;56 Suppl 2:149-51. Available on medind.nic.in

23. Belfrage P, Smedvig E, Gjessing L, Eggebo TM, Okland I. A randomized prospective study of Misoprostol and dinoproston for induction of labour. Acta Obstet Gynecol Scand. 2000 Dec;79(12):1065-8.

24. Neiger R, Greaves PC. Comparison between vaginal misoprostol and cervical dinoprostone for cervical ripening and labour induction. Tenn Med. 2001 Jan;94(1):25-7.

25. Buser D, Mora G, Arias F. A randomized comparison between misoprostol and dinoprostone for cervical ripening and labour induction in patients with unfavorable cervices. Obstet Gynecol. 1997 Apr;89(4):581-5.

26. Danielian P, Porter B, Ferri N, Summers J, Templeton A. Misoprostol for induction of labour at term: a more effective agent than dinoprostone vaginal gel. Br J Obstet Gynaecol. 1999 Aug;106(8):793-7.

\section{How to cite this article?}

Parate S, Fidvi J. A comparative study of single and double dose of intracervical Prostaglandin E2 gel for cervical ripening. Int J Med Res Rev 2015;3(5):484-489. doi: 10.17511/ijmrr.2015.i5.093. 